\title{
Pedagogy for Peace in University Extension: a Ludic Proposal with Cooperative Games
}

\section{Pedagogía para la paz en la extensión universitaria: una propuesta lúdica con juegos cooperativos}

\author{
Evelyn Cerdas-Agüero \\ Master in Human Rights and Education for Peace \\ Coordinator of the Project Aula Activa [Active Classroom] \\ Instituto de Estudios Latinoamericanos (IDELA) \\ Universidad Nacional \\ Costa Rica \\ Received: 1/30/2019 \\ Accepted: 3/20/2019 \\ DOI: https: //doi.org/10.15359/tdna.35-65.16
}

\begin{abstract}
This text, by using a qualitative approach of theoretical and reflexive analysis, aims to promote peace education as a pedagogical axis in university extension and to generate a reflection on the importance of incorporating the cooperative games in the extension process at the Universidad Nacional. It is concluded that education and group processes can be articulated around the cooperative
\end{abstract}

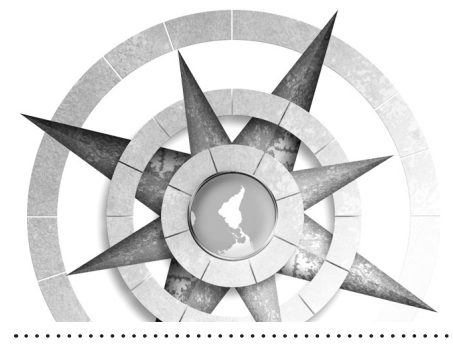


Se concluye que la educación y los procesos grupales se pueden articular en torno al juego cooperativo como eje fundamental que permite construir saberes colectivos, promover vivencias, así como el desarrollo de determinadas habilidades para el fortalecimiento de procesos grupales.

Palabras clave: Juegos cooperativos; educación para la paz; extensión, IDELA, Universidad Nacional

\section{Introduction}

The Institute of Latin American Studies (IDELA), through the extension project "Active Classroom: Cooperative games for education for peace" has worked in the area of education for peace recognizing it as an essential process for the construction and consolidation of a culture of peace and recognition of human rights. The project has been implemented as an innovative pedagogical process throughout diverse communities and groups in the country, incorporating a participatory methodology in education for peace that has privileged experiential processes through cooperative games; such proposal has contributed to teamwork, leadership, solidarity, integration, consensual decision-making, dialogue, non-violence, recognition of human rights and peaceful management of conflicts. Based on the experience gained in the implementation of the cited project, it is that the present work stems from IDELA as a qualitative approach of theoretical and reflective analysis, aimed at: promoting education for peace as a pedagogy tool in university extension; and spurring reflection on the transcendence of incorporating cooperative games in the extension process at UNA to promote dynamic spaces, collaborative and joint construction.

The incorporation of education for peace is considered important as the axis of university extension at UNA because it promotes full and effective participation of people, in communities and in society in general, creates tools of empowerment and recognition of the role each individual possess in the construction of a culture of peace through participation in personal, social, economic, political and cultural processes in the different spaces in which they develop. At the same time, it allows the creation of new joint proposals for peacebuilding in real scenarios from the participation and voice of the actors of society and the university.

Education for peace as a pedagogical proposal is aimed at fostering the culture of peace through creativity, the formation of values, respect for human rights and fundamental rights, justice, democracy, understanding, dialogue and solidarity, through processes focused on the search for the transformation of the human condition and society, social structures and cultural patterns 
that promote violence, injustice, disregard for human rights and the dignity of humans.

It is also important to recognize the link that exists between education for peace and related rights as proclaimed in the Costa Rican legislation under the constitutional scope; the Political Constitution of Costa Rica (1949) establishes in articles 1, 12, 20, 21, 26, 50 a vision of peace for its citizens as pertains to democracy, freedom, independence, non-slavery, respect for life, peaceful assembly and the pursuit of the well-being of people. These constitutional articles are quite explicit, however, it is necessary to mention that human rights are interdependent and the right to peace is visualized through other rights and individual guarantees (Title IV) among which can be cited the freedom of transit/movement (article 22), the right to private property and private domicile (article 23, 24, 45), non-slavery and cruel treatment (article 40), freedom of expression and information (art. 28, 29, 30) and equality (art. 33).

It is necessary to recognize the fundamental task that the public university holds, to work in favor of human rights and peace as a complex undertaking in society through extension with it as UNA's vision implies the promotion of communication and collaboration among the all actors of society, the preparation people and communities for their development. In addition, the university also contributes in:

... creating and transmitting knowledge in favor of human well-being, through actions that promote the transformation of society and drive it forward to higher stages of coexistence. It honors freedom, diversity, the pursuit of truth and natural and cultural sustainability, all in benefit of knowledge, equity, justice and the dignity of the human condition. (Organic Statute, 2015, preamble, paragraph 1).

In addition, education for peace favors the fulfillment of UNA's purposes as stipulated in its Organic Statute (2015), such as interdisciplinarity, which emphasizes "the permanent articulation between various disciplines and the search for their complementarity" (article 3.b), and critical thinking to promote "the systematic and permanent analysis of national and international realities, in order to determine their trends, and from such knowledge detect their problems, needs and strengths, to offer solution alternatives" (article 3.g). Both stated purposes are consistent with the commitment to promote UNA's principles and values such as inclusion, transformative knowledge, social commitment, "justice, the common good, unrestricted respect for human dignity, human rights and the rights of people 
and nature" (Organic Statute, 2015, article 1.a), as well as "the orientation of institutional tasks towards the common good, particularly towards the promotion and achievement of a better quality of life for the less favored social sectors" (article 2).

On the other hand, the implementation of cooperative games is also important in processes such as group work, extension and collective proposals, because these generate spaces for mutual recognition, allow to explore and facilitate creative solutions in a free environment, promote empathetic and cooperative relationships, participation, leadership, assertive communication, learning from mistakes, the consensual search for solutions and the learning of values and skills for coexistence. Processes generated whilst applying the game favor group cohesion, better relationships between people from different contexts and institutions that allow cooperative leadership, the creation of trust spaces, a broader vision of the different contexts and overall understanding for teamwork. In addition, they give rise to feelings, thoughts from within each individual, as a subject capable of showing autonomy, exercising their freedom of expression and recognition of their dignity as a human being.

\section{Education for peace: a Pedagogy for Transformation}

Education for peace is a pedagogical project and a human right aimed at the comprehension between individuals and peoples, cognitive, attitudinal and affective development; it is framed in two intertwining human rights, namely, education and peace. In accordance with the Universal Declaration of $\mathrm{Hu}$ man Rights (1948, article 26) "1. Everyone has the right to education (...) ", according to this same declaration and the International Covenant on Economic, Social and Cultural Rights (1966) education should be oriented to promote the development of the human being, the recognition of their dignity, respect for fundamental rights and liberties, understanding, acceptance and friendship.

In this sense, the right to education focuses on the human being, the interdependence of their rights and their interactions, in a way that allows the creation of respectful relationships in which the dignity of each individual is valued and their quality of life promoted, additionally, it brings about knowledge and the development of skills for life. This is how Freire (1997) states that education is a participatory process that seeks the transformation of people and society, understanding and awareness of oppression, therefore, constituting an education towards empowerment and 
freedom, for emancipation. According to Freire (2006), education is liberating by allowing people to assume their commitment and granting the recognition of the individual as an actor capable of transforming society, hence, the transformation of the individual, pursuit of freedom and respect are primordial.

University extension can be directed at erecting, through the components of education for peace, mechanisms by which people manage processes aimed at individual and collective transformation so that each person is recognized as a conductor of change and of reality, towards more solidary and harmonious ways of life to realize a more righteous life in community.

Each human being can direct their efforts as part of a solidarity action to live in peace, in freedom, to demonstrate against violence, social injustice, lack of opportunities, as established in the Universal Declaration of Human Rights (1948) in its $28^{\text {th }}$ article, all peoples have the right to live in peace, so fulfillment of respect for human rights and fundamental rights are imperative. Thus, peace is linked to the way of life, with the recognition and awareness of peace as a form of coexistence that starts from the individual human being and permeates to the community through social relationships among individuals, groups, peoples and nations, hence, peace is a right that has its realization in practice and this must be reflected in the interdisciplinarity by which the university operates.

Peace, is constituted as a fundamental condition for the realization of human rights, its respect and recognition, implies a collective, contextualized, intergenerational effort for its realization and consolidation, which cannot be invisible to the university in its interaction with society; the university seeks for the common good and to influence reality for it to be more just, free and democratic. From this perspective, peace is considered as an unfinished process, under construction, an "imperfect peace" of a permanent process, of constant pursuit "that tries to be built day by day in all scenarios, facilitating the analysis of ideas, values, attitudes and behaviors related to peace" (Martín, 2015, p.243); this constant experience is one in which UNA can influence by the creation of spaces where actions that create peace are appreciated and which combat all those actions and inactions that limit it.

The proposal of imperfect peace implies that there is no state of peace, absolute and perfect, but rather, a process that is discovered and built every day through practices carried out by people, institutions and, in general, the different actors of society, but for this, it is necessary to promote spaces of recognition, sensibilization, empowerment in sight 
of this imperative need, which at the same time is a challenge before the passivity and naturalization of the different forms of violence.

In this sense, it is regarded as a process that allows awareness to be taken of people, society and different contexts in order to construct reality collectively, cooperatively and promote a peaceful coexistence as "(...) a process by which human beings are self-constructing in communication with other human beings (...)" (López, 2006, p.9 cited by Gómez, 2010, p.126). It includes the development of skills, reflection, problem solving, cooperation, the resolution of conflicts and the search of opportunities for the transformation of the human condition (Harris and Lee, 2013).

Thus, it is proposed a pedagogy for life, freedom, respect for human rights and recognition of the intrinsic dignity of each human being towards the construction of more harmonious and committed relationships with the incidence on new ways of living in society, that at the same time, imply the collective construction of a dynamic process that is not neutral from the university nor communities perspectives, so that extension must be based on certain values and principles that seek to influence social change, stimulate reflective criticism of reality and take options in the event of unjust, oppressive and violent conditions.
It is important to recognize that the university, in its work of action and incidence in society through extension, can prioritize learning themes to be taken as pillars of education to build peace, which, also constitute important bases for building a fairer society, with more opportunities in which the common good is sought, this implies a social and individual commitment for the transformation of society, these pillars were pointed out by Delors (1996): leaning to be, learning to live together, learning to do and learning to know. As stated by Garcia (2016), such learnings, pillars of the development of a pedagogy for peace, imply a profound change in people, groups and society in general, towards a socially critical pedagogy, holistic and political, a process that can be built from the university along with communities, implies the internalization of values, the acquisition of knowledge and the development of skills in participative environments wherein reflection is generated; the approach of knowledge and learning in an integrated manner with their experiences and situations of social reality as those linked to human rights. It is also linked to the "delegitimization of violence in society as a political tool" (p.47) and the individual and collective commitment to recognize the forms of violence and influence them to transform the human condition and effect respect to the dignity of every human being.

lent conditions. 
The Cooperative Game: Space of encounters and Experiences

Games are activities that have been present in the development of human beings and have privileged their relationships since birth, which has made them indispensable in the evolution of humankind. At the same time, it is essential, both for the individual and the community, because it has meaning, expressive value and implies spiritual and social connections, cultural functions of expression and coexistence. These characteristics make games exceed the customary, according to Huizinga (2000) games do not refer to ordinary life, but are the recreation of another life, which can be imagined, built in the process and can also reflect elements of reality, "The game is not the "ordinary" life or life "properly said». Rather, it consists in escaping from it to a temporary sphere of activity that possesses its own tendency" (p.21), thus, it has a primordial function in human development since it recreates and reflects part of reality while implying freedom, meaning, it happens in itself and is outside current life, but it does not imply that it cannot manage its transformation; games form a model of society wherein diverse relationships occur that make sense when translated into reality and into human interactions in diverse contexts. The latter is cataloged by $\mathrm{Mi}$ randa (2008) as a mini society in which the formation of values is created in the direction of solidarity and cooperation, which implies that the game, in group and community integration, invigorates the process of social interaction that extends coexistence.

Thus cooperative games refer to non-traditional games (leisure activities) that seek to generate experiential spaces of learning characterized by participation, fun and cooperation based on freedom and respect for human dignity, they are:

(...) proposals that seek to diminish manifestations of aggressiveness in games promoting attitudes of awareness-raising attitudes, cooperation, communication and solidarity. They facilitate encounters with others and the proximity to nature. They seek the participation of all, with collective objectives prevailing over individual goals. People play with others and not against others; they play to overcome challenges or obstacles and not to overcome others (Pérez, 1998, p.1).

In this process the participants forge common goals, which implies a sense of cooperation, eliminating the space for competition, individualism or exclusion, instead, given way to participation; it is a meeting space that can be privileged in extension processes. 
According to Omeñaca and Ruiz (2005) the game is a source of happiness, jubilance, pleasure, constitutes an end in itself, is spontaneous, voluntary and free, promotes learning, is a form of expression, involves active participation, is a space of encounter with reality, it is a separate world in which experiences, learnedness and visions of the world are being built and recreated in which people are the center of the game's ludic process with their knowledge, skills, abilities, history and needs, and produces internalization, reflection, analysis, introspection, it also implies a personal process of reflection, internalization as well as attitudinal and cognitive processes. Furthermore, it privileges experiences, generates a learning process in which people are encouraged to share, relate, learn from mistakes, get to know each other, resolve and manage conflicts, create a climate of trust, practice assertive communication techniques, a win-win focused approach, strengthening of the decision-making and creation of organization and strategy planning spaces. Garaigordobil (2003) states that the game contributes to various aspects such as the intellect, because by playing one learns and obtains new experiences, knowledge is put into practice, problem solving proposals are generated, mistakes are made and successes attained, it also stimulates thinking, the generation of ideas, proposals and creativity; sociability allows for a space to meet with equals, get to know the people, recognize, accept and respect differences and similarities; the affective and emotional development, the game generates pleasure, joy, fun, freedom and spaces of free expression and to release tensions.

Likewise, they are part of the participatory methodology, which is a way of approaching the pedagogical, construction, planning and joint evaluation processes, essential elements of extension; also, it is characterized by being ludic, interactive, creative and flexible, in addition, it strengthens group cohesion, as well as being formative, because it gives priority to processes, promotes commitment among the participants and is characterized by being of experiential nature.

\section{Education for Peace in University Extension}

Two possibly foreseen proposal axes for incorporating into university extension are: education for peace as a transformational process that allows build, promote and consolidate a culture of peace; and the cooperative game as a space and process of dialogue of life and daily experiences, development of skills and empathy for group construction.

Education for peace focuses on the promotion of solidarity relationships, peaceful coexistence, alternatives for the peaceful resolution of conflicts, the commitment to transformation as part

236 Pedagogy for Peace in University Extension: a Ludic Proposal 
of daily practice and allows the generation of awareness of the role that the individual has in their community as an axis of advocacy and transformation, this role is important because education for peace is also a political proposal, as it seeks the transformation towards social justice. In this sense, extension should be considered as a process that allows the empowerment of people from their realities and contexts so that their relationships, life projects, initiatives and daily life have, as frame of reference, the continuous construction of peace and the recognition of human rights and human dignity.

Cooperative games as ludic techniques in participatory methodology are important in the university extension process because they promote processes centered on a vision of community in which learning and transformational proposals for society are built, within a solidary practice wherein freedom and rights are recognized, as well as cooperation between individuals, groups, communities and organizations in a field of recognition of co-responsibility towards a better quality of life and respect for the dignity of the human being. This is precisely what education for peace also seeks and what cooperative play contributes to, facilitating social processes centered on solidarity, trust, mutual respect and understanding.
Thus, education for peace can influence university extension:

- As a permanent training process that allows to recognize and experience the different techniques that transcend the ordinary giving rise to participation, affectivity, encounter through play and participatory activities.

- As a vision of participatory processes, towards collective construction, mutual listening and dialogue.

- By promoting human interactions and relationships that are respectful and trustworthy in communities as part of peaceful coexistence.

- By aiming at the construction of spaces and projects that address the prevention of violence.

- By integrating proposals towards a local and national contextualized project of formal and non-formal education for peace.

- Promote affirmation, empowerment, self-autonomy, as a social subject of rights that fulfills an important role in society and in the individual.

- Promote the right to peace.

On the other hand, the characteristics of the cooperative game provides it with a unique value in the context of working with groups and communities because it generates situations of social interaction in which attitudes and decision making are manifested, that reflect 
the realities of each person, group and context.

In addition, it represents dynamism, it is an environment in which interactions, relationships, and diverse events take place that are part of a process that is being built, that is, the game allows the construction of decision-making processes, conflict resolution, dialogue, confidence, consensus, proposals and sharing of goals, objectives and realities, which are necessary for university extension.

Likewise, it allows to build learning as a ludic process through individual interaction by considering what each individual knows and experiences, such as their own history; the interactions that occur between the members of the group or community; and the interactions with the environment, be it social, political, economic, historical or natural.

Cooperative games as part of the ludic can be constituted as an experience, a managerial space and a process that allows the following in extension processes.

- Promotion of dialogue among extension agents that allows knowing their capacities, realities, needs and proposals.

- Develop and strengthen management skills and skills in areas of competence for group work and community work such as assertive communication, dialogue, cooperative leadership, cooperation and conflict management.

- Develop a critical and reflective spirit regarding the power that the game has over community work and its possibilities.

- Develop skills and competencies in community groups to reflect on their conclusions about the actions and lived experiences with extension projects and throughout them.

- Encourage spaces for dialogue and reflection in communities, so that they are pleasant, emotional, cheerful, based on respect, participation and commitment.

- Promote human interactions and relationships within the community that are affective, respectful and trustworthy as part of a ludic process.

- Develop, through game, expression and communication in its various dimensions, as a human right and as a necessary element in the management and joint work for the development of actions.

- Address the full and integral experience of various issues

- Privilege teamwork. 


\section{What is Required for its Implementation?}

Training processes and creation of spaces with extension agents that allow:

- Knowledge sharing, critical reflection and experience sharing of education for peace and related issues by involving cognitive, attitudinal and affective components.

- The recognition of various education for peace opportunities from interdisciplinarity so that diverse languages and knowledges can be brought together to recognize the transcendence of interdisciplinary peace pedagogies.

- Processes of reflection and formulation of proposals based on dialogue, cooperation aimed at the construction of a culture of peace from the recognition of the human right to peace and its allowance to impact over some social needs.

- The recognition, in an experiential way and with theoretical contributions, of the power of the cooperative game and the possibilities it brings to group work and community approach.

- The importance of the game as a participatory methodology in the learning processes and as a socio-cultural activity.
- Promote the construction of interdisciplinary projects that allow the development of pedagogical proposals for peace.

\section{Conclusions}

This work is the result of practice and experiences with various groups through the extension project "Active Classroom: cooperative games for education for peace" of IDELA and a theoretical discussion that justifies, reflects on and establishes the importance of the game in extension but, also, the practical realization of education for peace as a pedagogical axis; these two elements conjugate for the construction of a culture of peace.

It is important to emphasize that, in education for peace and in cooperative games, the university, through extension, is providing prominence to the community, conceived dually as a social space and also as a group, which brings it close to its reality, history, knowledge, feelings, experiences and attitudes, which cannot escape from its context. This reality is presented before the eyes of the extension agent at the moment and during the process of encountering reality, which is nothing more than a dynamic, experiential space in which participative spaces must be provided to allow mutual incidence, knowledge and horizontal teamwork. 
The cooperative game recognizes the joint creation of a space for the analysis and reflection of diverse possibilities of development of the individual and the group regarding its affective, cognitive, attitudinal, social and learning attributes, while promoting and generating participatory integrating processes in which all people have a voice and freedom to put forth proposals, that is, an attitude towards the search for actions and collective proposals that incorporate personal experiences. In addition, it disseminates, recreates and strengthens traditions, beliefs, customs, social conducts and attitudes that are part of the cultural development of a community or group.

On the other hand, education for peace promotes group interactions that privilege: mutual knowledge, positive and non-violent relationships, cooperation, assertive and non-violent communication, sense of belonging, group cohesion and the pacific management of conflicts, all fundamental aspects in the experience and construction of a culture of peace that must accompany community extension work carried out by the university.

\section{References}

Agrelo, A. (sf.). Metodología participativa. Retrieved from http:// es.slideshare.net/andreagrelo/ metodologa-participativa (In Spanish)

United Nations General Assembly. (1966). Pacto Internacional de Derechos Económicos, Sociales y Culturales. Retrieved from http://www2.ohchr.org/spanish/law/cescr.htm (In Spanish)

United Nations General Assembly (1948). Declaración universal de derechos humanos, A/ RES/217A/III. Retrieved from http://www.ohchr.org/EN/ UDHR/Pages/Language.aspx?LangID=spn (In Spanish)

United Nations General Assembly (1978). Declaración sobre la preparación de las sociedades para vivir en paz, A/RES/33/73. Retrieved from http://daccessdds-ny.un.org/doc/RESOLU. TION/GEN/NRO/367/12/ IMG/NR036712.pdf?OpenElement (In Spanish)

Legislative Assembly of the Republic of Costa Rica. (1949). Constitución política de Costa Rica. Retrieved from http://www.constitution.org/cons/costaric.htm (In Spanish) 
Legislative Assembly of the Republic of Costa Rica. (1997). Ley sobre resolución alterna de conflictos y promoción de la paz social. Ley $\mathrm{N}$. 7727. Retrieved from http://www. derpublico.net/main.php/view_ photo?wa_id=13 (In Spanish)

Delors, J. (1996). La educación encierra un tesoro. Madrid: Santillana. Ediciones UNESCO. (In Spanish)

Freire, P. (1997). Pedagogía de la autonomía. Buenos Aires: Siglo XXI editores. (Indicar edición) (In Spanish)

Freire, P. (2006). Pedagogía de la esperanza. Buenos Aires: Siglo XXI editores. (Indicar edición). (In Spanish)

Garaigordobil, M. (2003). Diseño y evaluación de un programa de intervención socioemocional para promover la conducta prosocial y prevenir la violencia. España: CIDE. (Indicar edición) (In Spanish)

Garaigordobil, M. (2005). Diseño y evaluación de un programa de intervención socioemocional para promover la conducta prosocial y prevenir la violencia. España: CIDE. (Indicar edición) (In Spanish)
García, E. (2016). Educar para la paz desde los derechos humanos y la justicia social. En: Villar, C.; García, E; Martín, V.; Ramírez, C. (Coord.). Estudios en cultura de paz, conflictos, educación, y derechos humanos. Madrid: Editorial Síntesis. Pp.45-74. (In Spanish)

Gómez, M. E. (2010). La Educación para la paz aplicada a la tutoría académica en la Facultad de Ciencias Políticas y Sociales de la Universidad Autónoma del Estado de México. Revista Paz y Conflictos, 3, 2010, 123-139. Retrieved from http://www. ugr.es/ revpaz/tesinas/rpc_ n3_2010_dea3.pdf (In Spanish)

Harris, I. \& Lee, M. (2013). Peace education. North Carolina: McFarland $\&$ company, Inc., Publishers.

Huizinga, A. (2000). Homo ludens. Barcelona: Alianza editorial. (In Spanish)

Martín, V. (2015). Derechos humanos, ciudadanía crítica y cultura de paz. encuentros ontológicos desde la educación social. En Coca, C.; García, E.; Martín, V. \& Ramírez, C. (coords.), pp. 241256. Estudios en cultura de paz, conflictos, educación y derechos humanos. España: Editorial Síntesis. (In Spanish) 
Miranda, M. (2008). Trabalhando com jogos cooperativos: em busca de novos paradigmas na educação física. Sao Paulo: Papirus Editora. 2 edic. (In Portuguese)

Omeñaca, R. y Ruiz, J. (2005) Juegos cooperativos y educación física. Barcelona: Editorial Paidotribo. (In Spanish)

Pérez, E. (1998). Juegos cooperativos: juegos para el encuentro. Educación Física y deportes. Año 3, $\mathrm{N} \circ 9$. Buenos Aires. Retrieved from http://www.efdeportes. com/efd9/jue9.htm (In Spanish)
UNESCO. (1974). Recomendación sobre la educación para la comprensión, cooperación y la paz internacionales y la educación relativa a los derechos humanos y las libertades fundamentales. Retrieved from http://portal. unesco.org/es/ev.php-URL_ ID $=13088 \&$ URL_DO $=$ DO TOPIC\&URL_SECTION=201. html (In Spanish)

Universidad Nacional (2015). Estatuto Orgánico, Universidad Nacional. Retrieved from http://documentos.una.ac.cr/bitstream/ handle/unadocs/6693/ES. TATUTO-ORG\%C3\%81NICO-UNA-digital.pdf?sequence $=1 \&$ is Allowed $=\mathrm{y}$ (In Spanish) 